\title{
Paracrine effects of stem cells in wound healing and cancer progression (Review)
}

\author{
JÜRGEN DITTMER and BENJAMIN LEYH \\ Clinic for Gynecology, University of Halle, Halle/Saale, Germany \\ Received January 31, 2014; Accepted March 21, 2014
}

DOI: $10.3892 /$ ijo.2014.2385

\begin{abstract}
Stem cells play an important role in tissue repair and cancer development. The capacity to self-renew and to differentiate to specialized cells allows tissue-specific stem cells to rebuild damaged tissue and cancer stem cells to initiate and promote cancer. Mesenchymal stem cells, attracted to wounds and cancer, facilitate wound healing and support cancer progression primarily by secreting bioactive factors There is now growing evidence that, like mesenchymal stem cells, also tissue-specific and cancer stem cells manipulate their environment by paracrine actions. Soluble factors and microvesicles released by these stem cells have been shown to protect recipient cells from apoptosis and to stimulate neovascularization. These paracrine mechanisms may allow stem cells to orchestrate wound healing and cancer progression. Hence, understanding these stem cell-driven paracrine effects may help to improve tissue regeneration and cancer treatment.
\end{abstract}

\section{Contents}

1. Introduction

2. Paracrine effects of stem cells in tissue regeneration

3. Paracrine effects of stem cells in cancer

4. Conclusions

\section{Introduction}

Stem cells are characterized by their ability to self-renew and their capacity to differentiate to specialized cell types (1). Stem cells are found in most tissues of the human body and are required to maintain tissue homeostasis (2). They are also engaged in wound healing (3). A recent work by Fuchs et al on

Correspondence to: Professor Jürgen Dittmer, Klinik für Gynäkologie, Universität Halle, Ernst-Grube-Str. 40, D-06120 Halle/Saale, Germany

E-mail: juergen.dittmer@medizin.uni-halle.de

Key words: cancer stem cells, mesenchymal stem cells, angiogenesis, vascular endothelial growth factor, stromal cell-derived factor, microvesicles hair follicle stem cells suggests that the more adult stem cells are present in the injured area the faster the wound is healing (4). This might be explained by an accelerated recruitment of differentiated cells as generated by a higher number of stem cells. However, there is evidence that besides differentiation capacity also paracrine functions of stem cells are important in wound healing (5).

A stem cell type that, for quite some time, is known to apply paracrine effects to orchestrate wound healing is the mesenchymal stem cell (MSC), a multipotent stromal progenitor cell residing preferentially in bone marrow and adipose tissue $(6,7)$. MSCs are defined by their ability to differentiate to osteoblasts, chondroblasts and adipocytes, by plastic adherence and by a particular expression pattern of certain surface proteins $(8,9)$. Strongly attracted to wounds, MSCs are mobilized by injuries which they enter to modulate inflammatory responses and stimulate tissue regeneration (10). MSCs are a heterogeneous population and can also emerge from pericytes or endothelial cells (11), which may help to accelerate local MSC recruitment. MSCs were originally reported to contribute to tissue repair by trans-differentiating into cells, such as epithelial cells or neurons, that are required to restore the injured tissue (12-15). However, later it became evident that their paracrine activities are more important for wound healing than their differentiation potential $(11,16,17)$.

It is now well accepted that, also in cancer, stem-like cells, so-called cancer stem cells (CSCs), exist (18-21). These cells are thought to be responsible for tumor initiation and metastasis. As wounds that never heal (22) cancers resemble wounds in a number of aspects, e.g., in their ability to attract MSCs (23). CSCs are thought to contribute to tumor heterogeneity by generating different kind of differentiated cells. In breast cancer, CSCs can give rise to the so-called basal and luminal type of breast cancer cells (24). As suggested for adult stem cells, CSCs may have other functions besides recruitment of differentiated cells und may use paracrine activities to influence (tumor) tissue growth and maintenance. In this review, we will summarize the current knowledge on the importance of normal and cancer stem cells as producer of paracrine factors. Since there are a number of excellent reviews that address the paracrine functions of MSCs in wound healing and cancer $(11,25-30)$, we focussed here on the paracrine effects of non-MSC stem cells and describe MSC paracrine activities only for comparative reasons.

There are many ways by which cells can communicate in a paracrine manner. One way is by proteins, such as 
growth factors or cytokines. MSCs secret a plethora of such proteins $(28,29,31)$ some of which act as survival factors on neighboring (differentiated) cells, others stimulate angiogenesis. The cocktail of proteins that is secreted by cells is called the secretome (32). Besides the secretome, additional non-protein factors, such as lipids and RNAs, can be released from cells into the extracellular space. Some of these factors, in particular RNAs, may not leave the cell as soluble substances, but rather as cargos of microvesicles that are generated by the secreting cell. Microvesicles are circular fragments which can either be generated from endosomes (called exosomes; size range, 40-120 nm) or from the plasma membrane (called shedding vesicles; size range, 100-1,000 nm) (33-35). They can be distinguished from apoptotic bodies by their lack of DNA and histones. Both exosomes and shedding vesicles contain proteins of the lipid raft and lipids, such as cholesterol, as well as numerous soluble proteins and RNAs (mRNA and microRNA), e.g., in MSC-derived microvesicles, more than 700 proteins and $\sim 150$ miRNAs have been identified $(36,37)$. By interacting with microvesicles, cells can take up the microvesicular contents $(37,38)$ and use them for biological activities. Microvesicular RNA may be of particular importance. RNA from microvesicles can be translated into proteins (39) and RNase treatment often abrogates the effect of microvesicles on recipient cells $(40,41)$. Many effects of microvesicles have been described. Among them are inhibition of apoptosis, stimulation of stem cell activity or modulation of inflammatory responses (41-43).

\section{Paracrine effects of stem cells in tissue regeneration}

Myocardial infarction. Cardiac stem cells have been shown to improve recovery of the myocard from ischemia. This has been linked to their ability to differentiate to cardiomyocytes to replace the damaged cells. However, a recent report demonstrated that the differentiation potential of these cells alone was not sufficient for this repair (44). The cardioprotective effect of the cardiac stem cells also strictly depended upon the activation of signal transducer and activator of transcription 3 (STAT3) in the myocard. STAT3 can be activated by stromal cell derived factor-1 (SDF-1), a chemokine secreted by cardiac stem cells and known to support regeneration of the myocardial tissue (45). Inhibition of SDF-1 secretion blocked recovery. SDF-1 has a dual function in myocard repair. It recruits stem cells to the infarcted heart (45) and improves the survival of cardiomyocytes (46) by decreasing caspase 3 -dependent apoptosis (44). In the infarcted dog heart, recruitment of cardiac stem cells could be induced by administration of insulin growth factor-1 (IGF-1) and hepatocyte growth factor (HGF), two growth factors that stimulate the expansion of cardiac stem cells (47).

Besides cardiac stem cells, mesenchymal stem cells (MSCs) are able to improve post-ischemic recovery of the myocard (48). It was originally thought that multipotent MSC differentiate into cardiomyocyte-like cells to exert this effect, until it was found that the cocktail of proteins as secreted by MSC was sufficient for MSC-dependent recovery $(5,49,50)$. Interestingly, like cardiac stem cells, MSCs induce STAT3 phosphorylation in the myocard (51). Moreover, tolllike receptor 4 (TLR 4)-deficient MSCs that induce much higher STAT3 activation were more effective in repairing the myocardial tissue than their wild-type counterpart. In the presence of MSC-conditioned medium (CM), also SDF-1 levels were higher in the infarcted heart (52). The SDF-1 level could be increased when the CM was taken from MSCs that had been forced to express vascular endothelial growth factor (VEGF). Part of the SDF-1 protein derived from the MSCs, part from the myocard. Hence, MSCs and cardiac stem cells may exert their cardioprotective effect via the same route and by using the same secretory protein(s). In a porcine model, it could be confirmed that MSCs, in this case generated from human embryonic stem cells, can improve recovery of the myocard from ischemia via factors they secrete (53). However, in this study, the cardioprotective effect was accompanied by decreased phosphorylation of Smad2, an effector of the transforming growth factor $\beta$ pathway, and by reduced expression of caspase 3 . In addition, the component responsible for this effect of the MSC-derived CM was found to be rather large, a complex of $>1,000 \mathrm{kD}$. Later, a 20S proteasome, that copurifies with MSC-shedded exosomes, was identified as the likely candidate mediating MSC-dependent cardioprotection (54). The uptake of this proteosome by cardiomyocytes decreased the accumulation of misfolded proteins and may have therefore increased the survival of these cells. This is in agreement with the observation that MSC-derived CM upregulated antiapoptotic protein $\mathrm{Bcl} 2$ in cardiomyocytes and protected them from hypoxia-induced apoptosis (55).

Additionally, MSCs may stimulate angiogenesis in the infarcted myocard. MSC-derived CM was shown to activate endothelial cells and to increase capillary density in the infarcted heart $(50,56)$. Among the pro-angiogenic factors found in the secretome of MSCs are VEGF and basic fibroblast growth factor (bFGF) $(50,55,57,58)$. Blocking VEGF and bFGF by antibody treatment could partly diminish recovery by MSCs (58). In addition to VEGF and bFGF, cysteine-rich angiogenic inducer 61 (Cyr61) has been identified as an important MSC-derived soluble factor that stimulates angiogenesis in the infarcted myocard (59). The anti-fibrotic activity of MSCs is also considered to contribute to the beneficial effect of these cells on the infarcted myocard. MSC-derived CM reduced cardiac fibrosis by inhibiting the proliferation of cardiac fibroblast and, thereby, decreasing the deposition of collagen I, II and III $(60,61)$.

There are at least two more stem/progenitor cell types, the bone marrow-derived endothelial progenitor cell (EPC) and the skeletal muscle-derived stem cell (MDSC), which were shown to be capable of cardioprotection $(62,63)$. When EPCs were transplanted into the myocard, again, myocardial expression of SDF-1 was found to be increased (62). In addition, EPS may stimulate angiogenesis in the myocard by secreting thymosin $\beta 4$, a protein known to improve endothelial function (64). MDSCs were barely able to differentiate to cardiomyocytes, when implanted into the infarcted heart (65). Again it was their secretory activity that improved recovery from infarction. The major component of their secretome responsible for this effect was determined to be VEGF which stimulated angiogenesis. Blocking VEGF resulted in reduced neovascularization and adverse remodeling. Interestingly, mechanical stretching of MDSCs increased VEGF secretion. This finding, combined with the observation that mice that exercised after infarction showed higher myocardial VEGF 
levels and angiogenesis (66), may suggest that physical therapy after myocardial infarction improves recovery by increasing stem cell/VEGF-depending neovascularization (67).

In a recent study, the cardioprotective activities of cardiac stem cells, MSCs and EPCs were compared. Most effective in inducing myocyte differentiation and tube formation were cardiosphere-derived cells, a population of cells that contained cardiac stem cells and supporting cells (68). Compared to MSCs or bone marrow-derived mononuclear cells, these cells produced much higher levels of SDF-1, HGF and of the proangiogenic proteins VEGF and bFGF.

Duran et al asked the question if transplantation of cardiac and mesenchymal stem cells into the infarcted heart would change the cocktail of secreted factors (69). They first showed that, when cultured in vitro, both stem cell types secreted all of the 8 factors they had tested, including SDF-1 and VEGF. However, once transplanted into the infarcted heart, only VEGF and bFGF remained as the prominent proteins produced by both stem cell types. Along with the secretion of these two pro-angiogenic factors, both cell types stimulated neovascularization in the infarcted area which could not be attributed to differentiation of these stem cells to blood vessel cells. Surprisingly, SDF-1 was not found at any time point post-transplantation.

In summary, factors secreted by cardioprotective stem cells seem to have two major functions, i) to improve survival of cardiomyocytes; and ii) to stimulate neovascularization (Table I).

Damage of the nervous system. Similar to the ischemic myocard, the ischemic brain requires stem cell-secreted factors for recovery. Here, again, the pro-angiogenic growth factor VEGF secreted by transplanted human central nervous system stem cells was found to be critical for stem cell-dependent repair of stroke-induced lesions (70). Neural stem cells also stimulated axonal transport and induced increased dendritic branching and length (71). The effect of neural stem cell on dendritic plasticity was at least partially dependent upon thrombospondins 1 and 2, two proteins secreted by the stem cells. This is in line with the observation that knockout of thrombospondin 1 and 2 in mice reduced functional recovery after stroke (72). Neural stem cells were also reported to improve repair of spinal cord injuries in rats. Implanted into the lesion area these cells enhanced axonal outgrowth (73). Neutrotrophic factors, such as nerve growth factors (NGF) and brain-derived neurotrophic factor (BDNF), were found to be secreted by the neural stem cells and were made responsible for this effect. Spinal cord injured rats also benefitted from CM generated by bone-marrow derived MSCs (74). Improved motor recovery in the presence of this medium was the consequence of less extensive lesions. Though MSCs secrete NGF and BDNF, protect neurons from apoptosis (74) and stimulate neurite outgrowth in vitro (75), MSC-CM seem to have no effect on axonal outgrowth in vivo (74). Rather, MSC-CM appears to exert its neuroprotective effect in vivo by stimulating angiogenesis. This was again at least partly dependent on VEGF.

Kidney injury. Paracrine effects of stem cells also play a role in recovery from kidney injury. Tubular adult renal stem/progenitor cells (tARPC) have been reported to stimulate proliferation and to inhibit apoptosis of cisplatin-injured proximal tubular epithelial cells (76). This effect depended upon the secretion of inhibin A, an inhibitor of the TGF $\beta$ superfamily ligand activin known to inhibit renal tubulogenesis (77). Evidence was provided that inhibin A was transported to the tubular epithelial cells as RNA via microvesicles (76). Interestingly, inhibin A was only found in microvesicles shedded by tARPC that had encountered damaged tubular epithelial cells. For the recognition of apoptotic epithelial cells, toll receptor 2 (TLR2) was required. Also microvesicles shedded from bone marrow-derived mesenchymal stem cells were found to increase survival and proliferation of tubular cells after damage $(40,41)$. As RNase treatment abrogated this effect, again the transfer of certain RNAs by the epithelial cells was made responsible for this process. Furthermore, the presence of CD44 and CD29 on the surface of these microvesicles were found to be crucial for the communication between the MSC-derived microvesicles and tubular cells. In addition, soluble factors, namely VEGF, IGF-1 and HGF, as secreted by MSCs may contribute to the renoprotective effect of MSCs. These factors may be responsible for the increased survival of endothelial cells as observed in the presence of MSCs $(78,79)$. Interestingly, MSCs were found to attach to endothelial cells to form tubes in a cooperative manner (78).

In chronic kidney disease, exosomes from MSCs brought no improvement (80). However, non-fractionated CM from MSCs reduced disease progression and rescued renal function.

Other injuries. Stem cell-secreted factors have also been shown to improve recovery of liver from cirrhosis (81). In this case, Wistar rats poisoned with dimethylnitrosamine were treated with or without $\mathrm{CM}$ from $\mathrm{CD} 34^{+}$haematopoietic stem cells. The CM from these cells injected into the tail vein significantly increased liver repair and animal survival by blocking caspase 3-dependent apoptosis of liver cells. Among the 32 factors identified in the CM of the CD34+ ${ }^{+}$stem cells were a number of cytokines, including members of the $\mathrm{CXCL}$ chemokine family, known to be involved in wound healing. Liver regeneration is closely linked to CXC receptor 2 (82) which recognizes CXCL chemokines.

\section{Paracrine effects of stem cells in cancer}

Glioma. CD133+ glioma cancer-initiating/stem-like cells are able to suppress immune responses against the tumor by inhibiting T-cell effector activity and stimulating that of T-cell suppressor cells (Tregs) (83). These activities depended on the presence of phosphorylated STAT3 in the cancer stem cells and on the ability of these cells to activate STAT3 in the immune cells. Since CM from the glioma CSCs was as effective as the CSCs themselves in inducing immunosuppression (84), it is likely that CSC-secreted factors are responsible for STAT3 activation. Among the factors present in the CSC-derived CM were transforming growth factor $\beta 1$ (TGF $\beta 1$ ) and prostaglandin E2, two major secretory factors responsible for the immunosuppressive effects of MSCs (30). In addition, galectin- 3 , a $\beta$-galactoside-binding protein that in its soluble form can induce T-cell apoptosis (85), was found to be secreted by the glioma CSCs (84). Interestingly, galectin-3 is expressed by glioma cells, but not by astrocytes or oligodendrocytes (86). On its surface, the glioma CSCs also present the 
Table I. Paracrine actions of stem cells in tissue regeneration and cancer.

\begin{tabular}{|c|c|c|c|c|c|}
\hline Lesion & $\begin{array}{c}\text { Stem cell }(\mathrm{SC}) / \\
\text { progenitor cell }(\mathrm{PC}) \text { type }\end{array}$ & Secreted factor & Function & Comment & Refs. \\
\hline \multirow[t]{8}{*}{$\begin{array}{l}\text { Myocardial } \\
\text { infarction }\end{array}$} & \multirow[t]{2}{*}{ Cardiac SC } & SDF-1 & $\begin{array}{l}\text { Survival of } \\
\text { cardiomyocytes }\end{array}$ & $\begin{array}{l}\text { Induces STAT3 } \\
\text { activation }\end{array}$ & (44) \\
\hline & & VEGF, bFGF & Angiogenesis & & (69) \\
\hline & \multirow[t]{3}{*}{ Mesenchymal SC } & $\mathrm{CM}$ & Myocard repair & $\begin{array}{l}\text { Induces STAT3 } \\
\text { activation }\end{array}$ & (51) \\
\hline & & VEGF, bFGF, Cyr61 & Angiogenesis & & $(58,59,69)$ \\
\hline & & $\begin{array}{l}20 \mathrm{~S} \text { proteasomes } \\
\text { via exosomes }\end{array}$ & $\begin{array}{l}\text { Survival of } \\
\text { cardiomyocytes }\end{array}$ & $\begin{array}{l}\text { Reduces accumulation } \\
\text { of misfolded proteins }\end{array}$ & (54) \\
\hline & \multirow[t]{2}{*}{ Endothelial PC } & SDF-1 & Myocard repair & & (62) \\
\hline & & Thymosin $\beta 4$ & $\begin{array}{l}\text { Improvement of } \\
\text { endothelial function }\end{array}$ & & (64) \\
\hline & $\begin{array}{l}\text { Skeletal muscle- } \\
\text { derived SC }\end{array}$ & VEGF & Angiogenesis & $\begin{array}{l}\text { Higher VEGF levels by } \\
\text { mechanical stretching }\end{array}$ & $(65,66)$ \\
\hline \multirow[t]{2}{*}{ Stroke } & $\begin{array}{l}\text { Central nervous } \\
\text { system SC }\end{array}$ & VEGF & Neovascularization & & $(70)$ \\
\hline & Neural PC & $\begin{array}{l}\text { Thrombospondin } \\
1 \text { and } 2\end{array}$ & $\begin{array}{l}\text { Higher axonal transport } \\
\text { and dendritic branching }\end{array}$ & & (71) \\
\hline \multirow[t]{2}{*}{$\begin{array}{l}\text { Spinal cord } \\
\text { injury }\end{array}$} & Neural PC & NGF, BDNF & $\begin{array}{l}\text { Stimulation of axonal } \\
\text { outgrowth }\end{array}$ & & (73) \\
\hline & Mesenchymal SC & VEGF & Angiogenesis & & (74) \\
\hline \multirow[t]{2}{*}{$\begin{array}{l}\text { Acute kidney } \\
\text { injury }\end{array}$} & Tubular adult renal PC & $\begin{array}{l}\text { Inhibin A, } \\
\text { microvesicles }\end{array}$ & $\begin{array}{l}\text { Survival and } \\
\text { proliferation of } \\
\text { tubular cells }\end{array}$ & $\begin{array}{l}\text { Inhibin A probably } \\
\text { transmitted via } \\
\text { microvesicles }\end{array}$ & (76) \\
\hline & Mesenchymal SC & Microvesicles & $\begin{array}{l}\text { Survival and } \\
\text { proliferation of } \\
\text { tubular cells }\end{array}$ & & (40) \\
\hline $\begin{array}{l}\text { Chronic } \\
\text { kidney injury }\end{array}$ & Mesenchymal SC & $\mathrm{CM}$ & $\begin{array}{l}\text { Reduction of tubular } \\
\text { and glomular damage }\end{array}$ & $\begin{array}{l}\text { Exosomes are not } \\
\text { involved }\end{array}$ & (80) \\
\hline $\begin{array}{l}\text { Liver } \\
\text { cirrhosis }\end{array}$ & Haemotopoietic SC & $\mathrm{CM}$ & Survival of liver cells & $\begin{array}{l}\text { CXCL chemokines } \\
\text { may be involved }\end{array}$ & (81) \\
\hline \multirow[t]{2}{*}{ Glioma } & \multirow[t]{2}{*}{$\mathrm{CD}_{133^{+}}$glioma SC } & $\mathrm{CM}$ & Immunosuppression & $\begin{array}{l}\text { Requires STAT3 } \\
\text { activation in CSCs }\end{array}$ & $(83,84)$ \\
\hline & & VEGF, SDF-1 & Angiogenesis & & $(88,89)$ \\
\hline \multirow[t]{2}{*}{ Colon cancer } & $\mathrm{CD} 133^{+}$colon $\mathrm{SC}$ & $\begin{array}{l}\text { IL-4, ALDH1A1, } \\
\text { BLMH }\end{array}$ & Chemoresistance & & $(97,101)$ \\
\hline & Mesenchymal SC & PAI-1 & Stimulates migration & & (112) \\
\hline $\begin{array}{l}\text { Skin } \\
\text { papillomas }\end{array}$ & Skin papilloma SC & VEGF & $\begin{array}{l}\text { Angiogenesis, } \\
\text { maintains stemness }\end{array}$ & & $(113)$ \\
\hline Renal cancer & CD105+renal cancer SC & Exosomes & $\begin{array}{l}\text { Angiogenesis, } \\
\text { lung metastasis }\end{array}$ & $\begin{array}{l}\text { Exosomes contain } \\
\text { VEGF-RNA }\end{array}$ & (96) \\
\hline
\end{tabular}

ALDH1A1, aldehyde dehydrogenase family 1, member A1; BDNF, brain-derived neurotrophic factor; bFGF, basic fibroblast growth factor; BLMH, bleomycin hydrolase; CM, conditioned medium; Cyr61, cysteine-rich angiogenic inducer 61; IL-4, interleukin-4; NGF, nerve growth factor; PAI-1, plasminogen activator inhibitor-1; SDF-1, stromal cell derived factor-1; STAT3, signal transducer and activator of transcription 3; VEGF, vascular endothelial growth factor.

protein B7-H1 (84). This inhibitory co-stimulatory molecule inhibited T-cell proliferation through cell-cell interaction. These data indicate that glioma CSCs strongly contribute to the immunosuppression in gliomablastoma multiforme by paracrine effects as well as by mechanisms involving direct contacts with immune cells.

In addition to their immunosuppressive effect, glioma CSCs were found to stimulate angiogenesis. As a pro-angio- 
genic factor, $\mathrm{CD}_{133^{+}}$glioma CSCs secret substantial amounts of VEGF which leads to enhanced endothelial migration and tube formation (87). The level of secreted VEGF could be greatly enhanced by hypoxia. Forced overexpression of VEGF in CSCs also resulted in increased angiogenesis and tumor formation in vivo (88) confirming that CSCs can be a VEGF source to promote angiogenesis in glioma. Similar data were reported by Folkins et al, who compared glioma CSC high and low fractions (89). Besides VEGF, the CSC-high fraction also secreted SDF-1. Both VEGF and SDF-1 were necessary for the stimulatory effect of the CSC-high fraction on angiogenesis. Inhibition of either the VEGF receptor VEGFR2 or the SDF-1 receptor CXCR4 in endothelial cells equally blocked angiogenesis by CM from CSCs. CXCR4 is also highly expressed in glioma CSCs, where it stimulates VEGF secretion via the phosphoinositide 3-kinase (PI3K)/AKT pathway upon binding to SDF-1 (90). This suggests that SDF-1 has two functions in glioma CSC-driven angiogenesis: i) together with VEGF, it activates endothelial cells; and ii) it recruits more VEGF by stimulating its expression in glioma CSCs.

Interestingly, MSCs, which have been shown to stimulate angiogenesis in prostate cancer (91), suppress angiogenesis in glioma and hence inhibit glioma growth in vivo (92). Concomitantly, the expression of pro-angiogenic factors, such as bFGF, platelet-derived growth factor-BB (PDGF-BB) and IGF-1, were reduced suggesting that MSCs inhibited the secretion of these factors by the glioma cells. However, another study using glioma stromal mesenchymal stem-like cells (GS-MSLCs), which are MSC-like cells residing in glioma, demonstrated that MSCs are also able to promote angiogenesis (93). Apparently, the source the MSCs are isolated from is an important factor that determines the effect of MSCs in glioma (94).

Renal cancer. Pro-angiogenic activities can also be attributed to CSCs isolated from renal cancer (95). These CD105-expressing CSCs stimulated angiogenesis by secreting exosome-sized microvesicles (96). CD105-positive, but not CD105-negative microvesicles, contained RNAs encoding angiogenic factors, such as VEGF. The CSC-derived microvesicles induced invasion of human vascular endothelial cells, protected them from apoptosis and promoted endothelial/tumor cell adhesion. They also stimulated angiogenesis in Matrigel plug assays in vivo. Treatment of lung endothelial cells with these microvesicles increased their expression of VEGF receptor and of matrix metalloproteinases 2 and 9 . There is also evidence provided that these CSC-secreted microvesicles promote metastasis formation of renal cancer cells in the lung.

Colon cancer. Also colon $\mathrm{CD}_{133}{ }^{+} \mathrm{CSC}$ s support tumor survival by paracrine actions. The sensitivity of CD133- non-CSC colon cancer cells to 5-fluorouracil and oxaliplatin was shown to strongly increase when interleukin-4 (IL-4), a cytokine present in colon cancer and absent in normal colon, was blocked by an IL-4 specific antibody (97). Interestingly, CD133 ${ }^{+} \mathrm{CSCs}$ were identified as the source of IL-4, although, in colorectal cancer, $\mathrm{Th}_{2}$ lymphocytes, the major producer of this inflammatory cytokine, are significantly increased in numbers (98). The CSCs themselves also benefitted from this cytokine as it participated in sustaining their chemotherapy resistance.
Hence, CSC-derived IL-4 acted as both a paracine and autocrine survival factor in colon cancer. Blockage of IL-4 resulted in downregulation of anti-apoptotic proteins, such as Bcl-xL, suggesting that IL-4 protects colon cancer cells from cytotoxic drugs by inhibiting apoptosis. IL-4 has also been demonstrated to protect other cancer cell types, such as breast, bladder, prostate and thyroid cancer cells, from apoptosis $(99,100)$. This suggests that IL-4 may be of general importance for cancers to gain therapy resistance. Emmink et al identified another way by which colon CSCs may contribute to therapy resistance of colon cancer (101). Comparing the secretome of colon CSCs with that of more differentiated colon cancer cells in the bulk tumor they found that CSCs secreted much higher levels of aldehyde dehydrogenase family 1, member A1 (ALDH1A1) and bleomycin hydrolase (BLMH), two enzymes able to detoxify chemotherapeutics. They could show that CSC-secreted ALDH1A1 and BLMH protected the colon cancer cells from cyclophosphamide and bleomycin, respectively.

Ovarian cancer. Recently, ovarian CSCs have been reported to release CCL5 into the culture medium (102), a chemokine known to play a role in breast cancer metastasis and whose secretion can be triggered by co-culturing breast cancer cells with mesenchymal stem cells (103). CCL5 increased the migratory and metastatic potential of ovarian CSCs in an autocrine manner, but had little effect on non-CSC ovarian cancer cells. However, since the autocrine CCL5 feedback loop fueled expression of MMP-9 by CSCs, it is possible that secreted MMP-9, a protease involved in ECM degradation, facilitates invasion also of neighboring non-CSC tumor cells.

Breast cancer. In breast cancer, the vast majority of studies on paracrine effects of stem cells have been done with MSCs which by heavily communicating with breast cancer cells via many soluble factors are able to promote tumor progression $(26,104)$. Interestingly, MSCs may also affect breast CSCs. Liu et al demonstrated that IL-6-stimulated MSCs produce the chemokine CXCL7 which further fuels IL-6 secretion by breast cancer cancer cells (105). In the end, this feedback loop leads to the release of factors, such as IL-8, that cause the CSC pool to expand. In a different way, adipose-derived stem cells were found to increase the breast CSC population. By secreting PDGF-D, these stem cells induce epithelial-to-mesenchymal transition of breast cancer cells and, as a consequence, generate additional stem-like cancer cells (106).

In addition, breast CSCs may themselves be a provider of bioactive soluble factors. Comparative transcriptome analyses by serial analysis of gene expression, cDNA microarray and next generation sequencing of $\mathrm{CD} 44^{+} / \mathrm{CD} 24^{-}$breast CSCs and bulk tumor cells revealed a highly active TGF $\beta$ pathway in CSCs compared to non-CSC breast cancer cells $(107,108)$. Along with the activation of the TGF $\beta$ pathway, typical TGF $\beta$ target genes, such as plasminogen activator inhibitor-1 (PAI-1), were found to be highly upregulated in CSCs. PAI-1, a well-established unfavorable prognostic factor in breast cancer (109), is a secretory protein able to promote cellular migration and angiogenesis $(110,111)$. Since PAI-1 secreted by MSCs is able to enhance migratory activities of cancer cells (112) (Dittmer et al unpublished data), it is reasonable to assume that CSC-secreted PAI-1 may also affect cell motility. 


\section{Tissue regeneration}

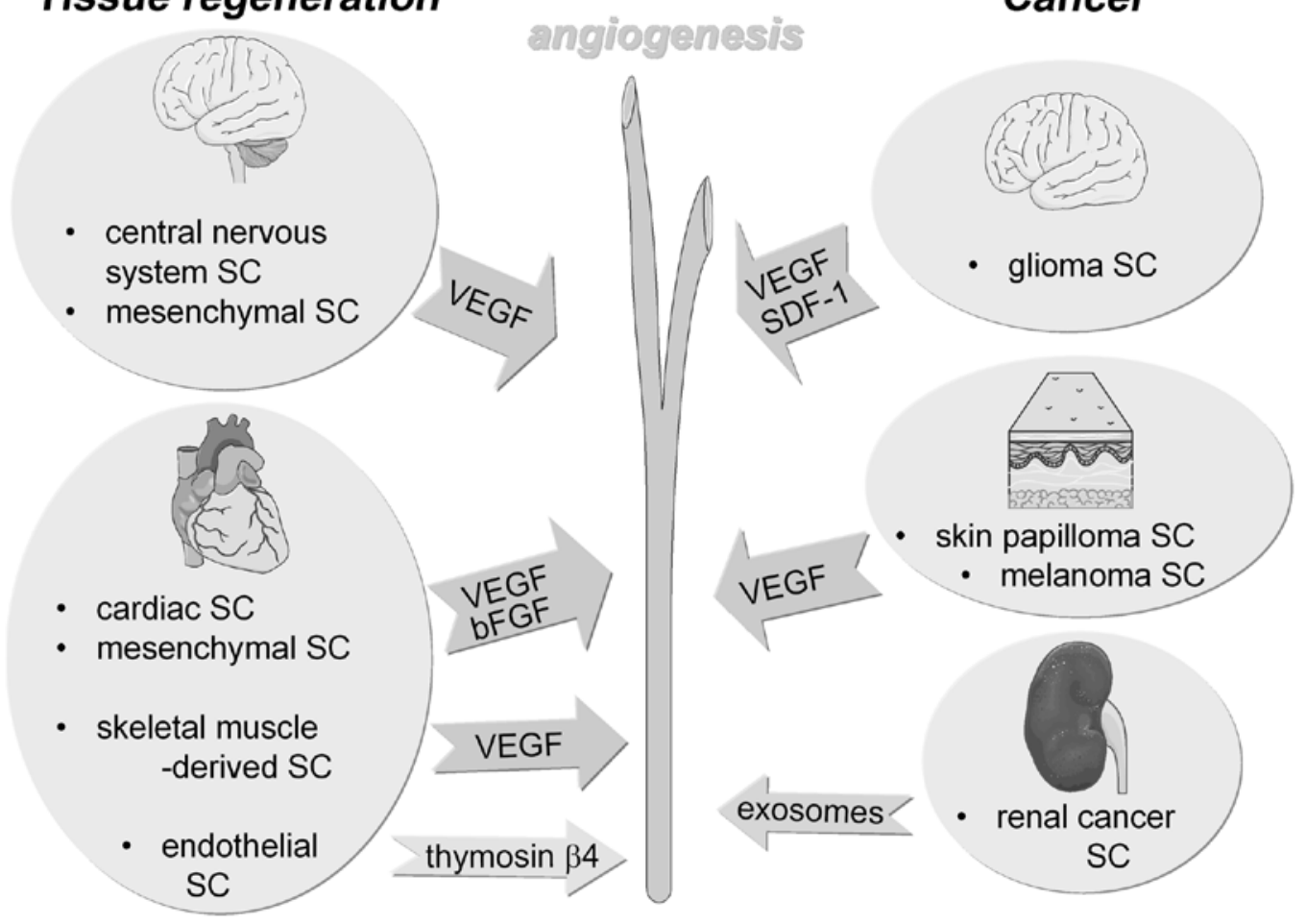

Figure 1. Pro-angiogenic effects of stem cells in tissue repair and cancer.

Other cancers. Connections between CSCs and endothelial cells have been demonstrated for squamous tumor of the skin. CSCs in skin papillomas produce large amounts of VEGF not only to trigger angiogenesis by stimulating neighboring VEGFR2-expressing endothelial cells, but also to maintain their stemness in an autocrine manner via the VEGF co-receptor neuropilin 1 (113). Blocking the function of either neuropilin 1 in CSCs or of VEGFR2 in endothelial cells reduced both microvessel density and CSC population. Hence, cutaneous CSCs are propagated in perivascular niches, which are maintained by the VEGF produced by the stem cells themselves. Also $\mathrm{CD}_{133^{+}}$melanoma stem cells have been shown to produce pro-angiogenic factors, such as VEGF (114). In pancreatic cancer, $\mathrm{CD} 133^{+}$cancer stem cells have been found to be the major source of VEGF-C (115).

\section{Conclusions}

Though the importance of paracrine effects for the functions of mesenchymal stem cells in tissue repair and cancer is well established, we just start to appreciate paracrine activities of other adult stem cells and cancer stem cells. In the past, tissue-specific adult stem cells and cancer stem cells were only viewed as providers of new (differentiated) cells either to fill the gap that has been caused by cell loss or to fuel tumor growth, respectively. Now, a new theme is emerging which ascribe to these stem cells an additional regulatory function in tissue maintenance or tumor progression. The so-called damage-associated molecular pattern (DAMP) after acute kidney injury may be a good example that shows how much stem cell-derived factors are involved in tissue repair (116). It seems that adult stem cells orchestrate wound healing by releasing specific factors that inhibit apoptosis of damaged cells and stimulate angiogenesis. The secretion of pro-angiogenic factors by stem cells may be of particular importance, since this activity is shared by many adult stem cells and cancer stem cells and often found to be essential for the stem cell-driven tissue regeneration and stem cell-dependent tumor progression, respectively (Fig. 1). Since delivery of oxygen and nutrients is essential for cell survival timely angiogenesis in tissue repair and cancer progression is a critical event. Stem cells may coordinate tissue repair/cancer progression by generating new cells and, by stimulating angiogenesis, simultaneously supplying these cells with the substances needed for survival. It is intriguing that endothelial cells are often in close contact with stem cells. One example is the haematopoietic stem cells which are positioned next to endothelial cells when residing in the endothelial niche in the bone marrow and whose expansion is dependent on endothelial cells (30). Also glioma stem cells are residing in endothelial niches (117) which seem to be of mutual benefit for both cell types (118). Perivascular niches have also been found to regulate dormancy of breast cancer cells (119) and maintain CSC populations in skin cancer (113). In addition, endothelial cells may be strongly involved in cancer metastasis (120). The link between cancer stem cells and endothelial cells may theoretically open new evenues to treat cancer stem cells that are usually resistant to chemotherapeutics and whose population may even expand in the presence of these drugs (121). Anti-angiogenic drugs may dislodge cancer stem cells from their endothelial feeding layer and stop them from growing and differentiating. However, anti-angiogenic drugs, such as anti-VEGF, have been tested for some time in clinical trials to suppress 
blood supply to the tumor and showed limited success for several reasons, e.g., because hypoxia was induced that then fueled cancer progression (122). More knowledge is required to understand the role of the cancer stem/endothelial cell interaction in cancer progression to find specific drugs that interfere with this kind of cell-cell communication.

In general, knowing that paracrine effects of stem cells strongly contribute to tissue repair and cancer may help to find new ways of therapeutical interventions to facilitate tissue regeneration and to improve cancer treatment, respectively.

\section{Acknowledgements}

This study was supported by the Deutsche Krebshilfe, grant no. 109271.

\section{References}

1. Fuchs $\mathrm{E}$ and Chen T: A matter of life and death: self-renewal in stem cells. EMBO Rep 14: 39-48, 2013.

2. Hsu YC and Fuchs E: A family business: stem cell progeny join the niche to regulate homeostasis. Nat Rev Mol Cell Biol 13: 103-114, 2012

3. Chun Q and Liang LS: Stem cell research, repairing, and regeneration medicine. Int J Low Extrem Wounds 11: 180-183, 2012.

4. Fuchs Y, Brown S, Gorenc T, Rodriguez J, Fuchs E and Steller H: Sept4/ARTS regulates stem cell apoptosis and skin regeneration. Science 341: 286-289, 2013.

5. Crisostomo PR, Wang M, Markel TA, Lahm T, Abarbanell AM, Herrmann JL and Meldrum DR: Stem cell mechanisms and paracrine effects: potential in cardiac surgery. Shock 28: 375-383, 2007.

6. Friedenstein AJ, Piatetzky S II and Petrakova KV: Osteogenesis in transplants of bone marrow cells. J Embryol Exp Morphol 16: 381-390, 1966

7. Zuk PA, Zhu M, Ashjian P, De Ugarte DA, Huang JI, Mizuno H, Alfonso ZC, Fraser JK, Benhaim P and Hedrick MH: Human adipose tissue is a source of multipotent stem cells. Mol Biol Cell 13: 4279-4295, 2002.

8. Dominici M, Le Blanc K, Mueller I, Slaper-Cortenbach I, Marini F, Krause D, Deans R, Keating A, Prockop D and Horwitz E: Minimal criteria for defining multipotent mesenchymal stromal cells. The International Society for Cellular Therapy position statement. Cytotherapy 8: 315-317, 2006.

9. Friedenstein AJ, Chailakhyan RK, Latsinik NV, Panasyuk AF and Keiliss-Borok IV: Stromal cells responsible for transferring the microenvironment of the hemopoietic tissues. Cloning in vitro and retransplantation in vivo. Transplantation 17: 331-340, 1974.

10. Brooke G, Cook M, Blair C, Han R, Heazlewood C, Jones B, Kambouris M, Kollar K, McTaggart S, Pelekanos R, Rice A, Rossetti T and Atkinson K: Therapeutic applications of mesenchymal stromal cells. Semin Cell Dev Biol 18: 846-858, 2007.

11. Bluguermann C, Wu L, Petrigliano F, McAllister D, Miriuka S and Evseenko DA: Novel aspects of parenchymal-mesenchymal interactions: from cell types to molecules and beyond. Cell Biochem Funct 31: 271-280, 2013.

12. Chen J, Li Y, Wang L, Zhang Z, Lu D, Lu M and Chopp M: Therapeutic benefit of intravenous administration of bone marrow stromal cells after cerebral ischemia in rats. Stroke 32: 1005-1011, 2001.

13. Ortiz LA, Gambelli F, McBride C, Gaupp D, Baddoo M, Kaminski N and Phinney DG: Mesenchymal stem cell engraftment in lung is enhanced in response to bleomycin exposure and ameliorates its fibrotic effects. Proc Natl Acad Sci USA 100: 8407-8411, 2003.

14. Park KS, Jung KH, Kim SH, Kim KS, Choi MR, Kim Y and Chai YG: Functional expression of ion channels in mesenchymal stem cells derived from umbilical cord vein. Stem Cells 25: 2044-2052, 2007

15. Rojas M, Xu J, Woods CR, Mora AL, Spears W, Roman J and Brigham KL: Bone marrow-derived mesenchymal stem cells in repair of the injured lung. Am J Respir Cell Mol Biol 33: 145-152, 2005.
16. Baraniak PR and McDevitt TC: Stem cell paracrine actions and tissue regeneration. Regen Med 5: 121-143, 2010.

17. Kassis I, Vaknin-Dembinsky A and Karussis D: Bone marrow mesenchymal stem cells: agents of immunomodulation and neuroprotection. Curr Stem Cell Res Ther 6: 63-68, 2011.

18. Clevers H: The cancer stem cell: premises, promises and challenges. Nat Med 17: 313-319, 2011.

19. Gupta PB, Chaffer CL and Weinberg RA: Cancer stem cells: mirage or reality? Nat Med 15: 1010-1012, 2009.

20. Visvader JE and Lindeman GJ: Cancer stem cells in solid tumours: accumulating evidence and unresolved questions. Nat Rev Cancer 8: 755-768, 2008

21. Dittmer J and Rody A: Stem cells in breast cancer. Histol Histopathol 28: 827-838, 2013.

22. Dvorak HF: Tumors: wounds that do not heal. Similarities between tumor stroma generation and wound healing. N Engl J Med 315: 1650-1659, 1986.

23. Kidd S, Spaeth E, Klopp A, Andreeff M, Hall B and Marini FC: The (in) auspicious role of mesenchymal stromal cells in cancer: be it friend or foe. Cytotherapy 10: 657-667, 2008

24. Gupta PB, Fillmore CM, Jiang G, Shapira SD, Tao K, Kuperwasser C and Lander ES: Stochastic state transitions give rise to phenotypic equilibrium in populations of cancer cells. Cell 146: 633-644, 2011

25. Ren G, Chen X, Dong F, Li W, Ren X, Zhang Y and Shi Y: Concise review: mesenchymal stem cells and translational medicine: emerging issues. Stem Cells Transl Med 1: 51-58, 2012.

26. Cuiffo BG and Karnoub AE: Mesenchymal stem cells in tumor development: emerging roles and concepts. Cell Adh Migr 6: 220-230, 2012

27. Tetta C, Consiglio AL, Bruno S, Tetta E, Gatti E, Dobreva M, Cremonesi $F$ and Camussi G: The role of microvesicles derived from mesenchymal stem cells in tissue regeneration; a dream for tendon repair? Muscles Ligaments Tendons J 2: 212-221, 2012.

28. Zimmerlin L, Park TS, Zambidis ET, Donnenberg VS and Donnenberg AD: Mesenchymal stem cell secretome and regenerative therapy after cancer. Biochimie 95: 2235-2245, 2013.

29. Paul G and Anisimov SV: The secretome of mesenchymal stem cells: Potential implications for neuroregeneration. Biochimie 95: 2246-2256, 2013

30. Frenette PS, Pinho S, Lucas D and Scheiermann C: Mesenchymal stem cell: keystone of the hematopoietic stem cell niche and a stepping-stone for regenerative medicine. Annu Rev Immunol 31: 285-316, 2013

31. Parekkadan B, van Poll D, Suganuma K, Carter EA, Berthiaume F, Tilles AW and Yarmush ML: Mesenchymal stem cell-derived molecules reverse fulminant hepatic failure. PLoS One 2: e941, 2007.

32. Agrawal GK, Jwa NS, Lebrun MH, Job D and Rakwal R: Plant secretome: unlocking secrets of the secreted proteins. Proteomics 10: 799-827, 2010.

33. Camussi G, Deregibus MC, Bruno S, Cantaluppi V and Biancone L: Exosomes/microvesicles as a mechanism of cellto-cell communication. Kidney Int 78: 838-848, 2010.

34. Muralidharan-Chari V, Clancy JW, Sedgwick A and D'SouzaSchorey C: Microvesicles: mediators of extracellular communication during cancer progression. J Cell Sci 123: 1603-1611, 2010.

35. Meckes DG Jr and Raab-Traub N: Microvesicles and viral infection. J Virol 85: 12844-12854, 2011.

36. Kim HS, Choi DY, Yun SJ, Choi SM, Kang JW, Jung JW, Hwang D, Kim KP and Kim DW: Proteomic analysis of microvesicles derived from human mesenchymal stem cells. J Proteome Res 11: 839-849, 2012.

37. Collino F, Deregibus MC, Bruno S, Sterpone L, Aghemo G, Viltono L, Tetta C and Camussi G: Microvesicles derived from adult human bone marrow and tissue specific mesenchymal stem cells shuttle selected pattern of miRNAs. PLoS One 5: e11803, 2010.

38. Yuan A, Farber EL, Rapoport AL, Tejada D, Deniskin R, Akhmedov NB and Farber DB: Transfer of microRNAs by embryonic stem cell microvesicles. PLoS One 4: e4722, 2009.

39. Valadi H, Ekstrom K, Bossios A, Sjostrand M, Lee JJ and Lotvall JO: Exosome-mediated transfer of mRNAs and microRNAs is a novel mechanism of genetic exchange between cells. Nat Cell Biol 9: 654-659, 2007.

40. Bruno S, Grange C, Deregibus MC, Calogero RA, Saviozzi S, Collino F, Morando L, Busca A, Falda M, Bussolati B, Tetta C and Camussi G: Mesenchymal stem cell-derived microvesicles protect against acute tubular injury. J Am Soc Nephrol 20: $1053-1067,2009$. 
41. Gatti S, Bruno S, Deregibus MC, Sordi A, Cantaluppi V, Tetta $\mathrm{C}$ and Camussi G: Microvesicles derived from human adult mesenchymal stem cells protect against ischaemiareperfusion-induced acute and chronic kidney injury. Nephrol Dial Transplant 26: 1474-1483, 2011.

42. Ratajczak J, Miekus K, Kucia M, Zhang J, Reca R, Dvorak P and Ratajczak MZ: Embryonic stem cell-derived microvesicles reprogram hematopoietic progenitors: evidence for horizontal transfer of mRNA and protein delivery. Leukemia 20: 847-856, 2006.

43. Ardoin SP, Shanahan JC and Pisetsky DS: The role of microparticles in inflammation and thrombosis. Scand J Immunol 66 159-165, 2007.

44. Huang $\mathrm{C}, \mathrm{Gu} \mathrm{H}, \mathrm{Yu}$ Q, Manukyan MC, Poynter JA and Wang M: Sca- $1^{+}$cardiac stem cells mediate acute cardioprotection via paracrine factor SDF-1 following myocardial ischemia/reperfusion. PLoS One 6: e29246, 2011.

45. Askari AT, Unzek S, Popovic ZB, Goldman CK, Forudi F, Kiedrowski M, Rovner A, Ellis SG, Thomas JD, DiCorleto PE, Topol EJ and Penn MS: Effect of stromal-cell-derived factor 1 on stem-cell homing and tissue regeneration in ischaemic cardiomyopathy. Lancet 362: 697-703, 2003.

46. Hu X, Dai S, Wu WJ, Tan W, Zhu X, Mu J, Guo Y, Bolli R and Rokosh G: Stromal cell derived factor-1 alpha confers protection against myocardial ischemia/reperfusion injury: role of the cardiac stromal cell derived factor-1 alpha CXCR4 axis. Circulation 116: 654-663, 2007.

47. Linke A, Muller P, Nurzynska D, Casarsa C, Torella D, Nascimbene A, Castaldo C, Cascapera S, Bohm M, Quaini F, Urbanek K, Leri A, Hintze TH, Kajstura J and Anversa P: Stem cells in the dog heart are self-renewing, clonogenic, and multipotent and regenerate infarcted myocardium, improving cardiac function. Proc Natl Acad Sci USA 102: 8966-8971, 2005.

48. Nesselmann C, Ma N, Bieback K, Wagner W, Ho A, Konttinen YT, Zhang H, Hinescu ME and Steinhoff G: Mesenchymal stem cells and cardiac repair. J Cell Mol Med 12: 1795-1810, 2008.

49. Noiseux N, Gnecchi M, Lopez-Ilasaca M, Zhang L, Solomon SD, Deb A, Dzau VJ and Pratt RE: Mesenchymal stem cells overexpressing Akt dramatically repair infarcted myocardium and improve cardiac function despite infrequent cellular fusion or differentiation. Mol Ther 14: 840-850, 2006.

50. Uemura R, Xu M, Ahmad N and Ashraf M: Bone marrow stem cells prevent left ventricular remodeling of ischemic heart through paracrine signaling. Circ Res 98: 1414-1421, 2006.

51. Wang Y, Abarbanell AM, Herrmann JL, Weil BR, Manukyan MC, Poynter JA and Meldrum DR: TLR4 inhibits mesenchymal stem cell (MSC) STAT3 activation and thereby exerts deleterious effects on MSC-mediated cardioprotection. PLoS One 5: e14206, 2010.

52. Tang JM, Wang JN, Zhang L, Zheng F, Yang JY, Kong X, Guo LY, Chen L, Huang YZ, Wan Y and Chen SY: VEGF/ SDF-1 promotes cardiac stem cell mobilization and myocardial repair in the infarcted heart. Cardiovasc Res 91: 402-411, 2011.

53. Timmers L, Lim SK, Arslan F, Armstrong JS, Hoefer IE, Doevendans PA, Piek JJ, El Oakley RM, Choo A, Lee CN, Pasterkamp G and de Kleijn DP: Reduction of myocardial infarct size by human mesenchymal stem cell conditioned medium. Stem Cell Res 1: 129-137, 2007.

54. Lai RC, Tan SS, Teh BJ, Sze SK, Arslan F, de Kleijn DP, Choo A and Lim SK: Proteolytic potential of the MSC exosome proteome: Implications for an exosome-mediated delivery of therapeutic proteasome. Int J Proteomics 2012: 971907, 2012

55. Xu M, Uemura R, Dai Y, Wang Y, Pasha Z and Ashraf M: In vitro and in vivo effects of bone marrow stem cells on cardiac structure and function. J Mol Cell Cardiol 42: 441-448, 2007.

56. Timmers L, Lim SK, Hoefer IE, Arslan F, Lai RC, van Oorschot AA, Goumans MJ, Strijder C, Sze SK, Choo A, Piek JJ, Doevendans PA, Pasterkamp G and de Kleijn DP: Human mesenchymal stem cell-conditioned medium improves cardiac function following myocardial infarction. Stem Cell Res 6: 206-214, 2011.

57. Gnecchi M, He H, Noiseux N, Liang OD, Zhang L, Morello F, $\mathrm{Mu}$ H, Melo LG, Pratt RE, Ingwall JS and Dzau VJ: Evidence supporting paracrine hypothesis for Akt-modified mesenchymal stem cell-mediated cardiac protection and functional improvement. FASEB J 20: 661-669, 2006.

58. Kinnaird T, Stabile E, Burnett MS, Shou M, Lee CW, Barr S Fuchs $\mathrm{S}$ and Epstein SE: Local delivery of marrow-derived stromal cells augments collateral perfusion through paracrine mechanisms. Circulation 109: 1543-1549, 2004.
59. Estrada R, Li N, Sarojini H, An J, Lee MJ and Wang E: Secretome from mesenchymal stem cells induces angiogenesis via Cyr61. J Cell Physiol 219: 563-571, 2009.

60. Ohnishi S, Sumiyoshi H, Kitamura S and Nagaya N: Mesenchymal stem cells attenuate cardiac fibroblast proliferation and collagen synthesis through paracrine actions. FEBS Lett 581: 3961-3966, 2007

61. Xu X, Xu Z, Xu Y and Cui G: Effects of mesenchymal stem cell transplantation on extracellular matrix after myocardial infarction in rats. Coron Artery Dis 16: 245-255, 2005.

62. Cho HJ, Lee N, Lee JY, Choi YJ, Ii M, Wecker A, Jeong JO, Curry C, Qin G and Yoon YS: Role of host tissues for sustained humoral effects after endothelial progenitor cell transplantation into the ischemic heart. J Exp Med 204: 3257-3269, 2007.

63. Oshima H, Payne TR, Urish KL, Sakai T, Ling Y, Gharaibeh B, Tobita K, Keller BB, Cummins JH and Huard J: Differential myocardial infarct repair with muscle stem cells compared to myoblasts. Mol Ther 12: 1130-1141, 2005.

64. Kupatt C, Bock-Marquette I and Boekstegers P: Embryonic endothelial progenitor cell-mediated cardioprotection requires thymosin beta4. Trends Cardiovasc Med 18: 205-210, 2008.

65. Payne TR, Oshima H, Okada M, Momoi N, Tobita K, Keller BB, Peng $\mathrm{H}$ and Huard J: A relationship between vascular endothelial growth factor, angiogenesis, and cardiac repair after muscle stem cell transplantation into ischemic hearts. J Am Coll Cardiol 50: 1677-1684, 2007.

66. Wu G, Rana JS, Wykrzykowska J, Du Z, Ke Q, Kang P, Li J and Laham RJ: Exercise-induced expression of VEGF and salvation of myocardium in the early stage of myocardial infarction. Am J Physiol Heart Circ Physiol 296: H389-H395, 2009.

67. Ambrosio F, Wolf SL, Delitto A, Fitzgerald GK, Badylak SF, Boninger ML and Russell AJ: The emerging relationship between regenerative medicine and physical therapeutics. Phys Ther 90: 1807-1814, 2010.

68. Li TS, Cheng K, Malliaras K, Smith RR, Zhang Y, Sun B, Matsushita N, Blusztajn A, Terrovitis J, Kusuoka H, Marban L and Marban E: Direct comparison of different stem cell types and subpopulations reveals superior paracrine potency and myocardial repair efficacy with cardiosphere-derived cells. J Am Coll Cardiol 59: 942-953, 2012.

69. Duran JM, Makarewich CA, Sharp TE, Starosta T, Zhu F, Hoffman NE, Chiba Y, Madesh M, Berretta RM, Kubo H and Houser SR: Bone-derived stem cells repair the heart after myocardial infarction through transdifferentiation and paracrine signaling mechanisms. Circ Res 113: 539-552, 2013.

70. Horie N, Pereira MP, Niizuma K, Sun G, Keren-Gill H, Encarnacion A, Shamloo M, Hamilton SA, Jiang K, Huhn S, Palmer TD, Bliss TM and Steinberg GK: Transplanted stem cell-secreted vascular endothelial growth factor effects poststroke recovery, inflammation, and vascular repair. Stem Cells 29: 274-285, 2011.

71. Andres RH, Horie N, Slikker W, Keren-Gill H, Zhan K, Sun G, Manley NC, Pereira MP, Sheikh LA, McMillan EL, Schaar BT, Svendsen CN, Bliss TM and Steinberg GK: Human neural stem cells enhance structural plasticity and axonal transport in the ischaemic brain. Brain 134: 1777-1789, 2011.

72. Liauw J, Hoang S, Choi M, Eroglu C, Sun GH, Percy M, Wildman-Tobriner B, Bliss T, Guzman RG, Barres BA and Steinberg GK: Thrombospondins 1 and 2 are necessary for synaptic plasticity and functional recovery after stroke. J Cereb Blood Flow Metab 28: 1722-1732, 2008.

73. Lu P, Jones LL, Snyder EY and Tuszynski MH: Neural stem cells constitutively secrete neurotrophic factors and promote extensive host axonal growth after spinal cord injury. Exp Neurol 181: 115-129, 2003

74. Cantinieaux D, Quertainmont R, Blacher S, Rossi L, Wanet T, Noel A, Brook G, Schoenen J and Franzen R: Conditioned medium from bone marrow-derived mesenchymal stem cells improves recovery after spinal cord injury in rats: an original strategy to avoid cell transplantation. PLoS One 8: e69515, 2013.

75. Crigler L, Robey RC, Asawachaicharn A, Gaupp D and Phinney DG: Human mesenchymal stem cell subpopulations express a variety of neuro-regulatory molecules and promote neuronal cell survival and neuritogenesis. Exp Neurol 198: 54-64, 2006.

76. Sallustio F, Costantino V, Cox SN, Loverre A, Divella C, Rizzi M and Schena FP: Human renal stem/progenitor cells repair tubular epithelial cell injury through TLR2-driven inhibin-A and microvesicle-shuttled decorin. Kidney Int 83: 392-403, 2013. 
77. Maeshima A, Zhang YQ, Furukawa M, Naruse T and Kojima I: Hepatocyte growth factor induces branching tubulogenesis in MDCK cells by modulating the activin-follistatin system. Kidney Int 58: 1511-1522, 2000.

78. Togel F, Weiss K, Yang Y, Hu Z, Zhang P and Westenfelder C: Vasculotropic, paracrine actions of infused mesenchymal stem cells are important to the recovery from acute kidney injury. Am J Physiol Renal Physiol 292: F1626-1635, 2007.

79. Imberti B, Morigi M, Tomasoni S, Rota C,Corna D, Longaretti L, Rottoli D, Valsecchi F, Benigni A, Wang J, Abbate M, Zoja C and Remuzzi G: Insulin-like growth factor-1 sustains stem cell mediated renal repair. J Am Soc Nephrol 18: 2921-2928, 2007.

80. Van Koppen A, Joles JA, van Balkom BW, Lim SK, de Kleijn D, Giles RH and Verhaar MC: Human embryonic mesenchymal stem cell-derived conditioned medium rescues kidney function in rats with established chronic kidney disease. PLoS One 7 : e38746, 2012.

81. Mintz PJ, Huang KW, Reebye V, Nteliopoulos G, Lai HS, Saetrom P, Kasahara N, Jensen S, Pai M, Gordon MY, Marley SB, Behan R, Spalding DR, Haoudi A, Emara MM, Nicholls J, Rossi JJ and Habib NA: Exploiting human CD34 stem cell-conditioned medium for tissue repair. Mol Ther 22: $149-159,2014$

82. Hogaboam CM, Bone-Larson CL, Steinhauser ML, Lukacs NW Colletti LM, Simpson KJ, Strieter RM and Kunkel SL: Novel CXCR2-dependent liver regenerative qualities of ELR-containing CXC chemokines. FASEB J 13: 1565-1574, 1999.

83. Wei J, Barr J, Kong LY, Wang Y, Wu A, Sharma AK, Gumin J, Henry V, Colman H, Priebe W, Sawaya R, Lang FF and Heimberger AB: Glioblastoma cancer-initiating cells inhibit T-cell proliferation and effector responses by the signal transducers and activators of transcription 3 pathway. Mol Cancer Ther 9: 67-78, 2010

84. Wei J, Barr J, Kong LY, Wang Y, Wu A, Sharma AK, Gumin J, Henry V, Colman H, Sawaya R, Lang FF and Heimberger AB: Glioma-associated cancer-initiating cells induce immunosuppression. Clin Cancer Res 16: 461-473, 2010.

85. Peng W, Wang HY, Miyahara Y, Peng G and Wang RF: Tumor-associated galectin-3 modulates the function of tumor-reactive T cells. Cancer Res 68: 7228-7236, 2008.

86. Kuklinski S, Pesheva P, Heimann C, Urschel S, Gloor S, Graeber S, Herzog V, Pietsch T, Wiestler OD and Probstmeier R: Expression pattern of galectin-3 in neural tumor cell lines. J Neurosci Res 60: 45-57, 2000.

87. Bao S, Wu Q, Sathornsumetee S, Hao Y, Li Z, Hjelmeland AB, Shi Q, McLendon RE, Bigner DD and Rich JN: Stem cell-like glioma cells promote tumor angiogenesis through vascular endothelial growth factor. Cancer Res 66: 7843-7848, 2006.

88. Oka N, Soeda A, Inagaki A, Onodera M, Maruyama H, Hara A, Kunisada T, Mori $\mathrm{H}$ and Iwama T: VEGF promotes tumorigenesis and angiogenesis of human glioblastoma stem cells. Biochem Biophys Res Commun 360: 553-559, 2007.

89. Folkins C, Shaked Y, Man S, Tang T, Lee CR, Zhu Z, Hoffman RM and Kerbel RS: Glioma tumor stem-like cells promote tumor angiogenesis and vasculogenesis via vascular endothelial growth factor and stromal-derived factor 1 . Cancer Res 69: 7243-7551, 2009.

90. Ping YF, Yao XH, Jiang JY, Zhao LT, Yu SC, Jiang T, Lin MC, Chen JH, Wang B, Zhang R, Cui YH, Qian C, Wang J and Bian XW: The chemokine CXCL12 and its receptor CXCR4 promote glioma stem cell-mediated VEGF production and tumour angiogenesis via PI3K/AKT signalling. J Pathol 224: 344-354, 2011.

91. Lin G, Yang R, Banie L, Wang G, Ning H, Li LC, Lue TF and Lin CS: Effects of transplantation of adipose tissue-derived stem cells on prostate tumor. Prostate 70: 1066-1173, 2010.

92. Ho IA, Toh HC, Ng WH, Teo YL, Guo CM, Hui KM and Lam PY: Human bone marrow-derived mesenchymal stem cells suppress human glioma growth through inhibition of angiogenesis. Stem Cells 31: 146-155, 2013

93. Kong BH, Shin HD, Kim SH, Mok HS, Shim JK, Lee JH, Shin HJ, Huh YM, Kim EH, Park EK, Chang JH, Kim DS, Hong YK, Lee SJ and Kang SG: Increased in vivo angiogenic effect of glioma stromal mesenchymal stem-like cells on glioma cancer stem cells from patients with glioblastoma. Int J Oncol 42: 1754-1762, 2013

94. Akimoto K, Kimura K, Nagano M, Takano S, To'a Salazar G, Yamashita T and Ohneda O: Umbilical cord blood-derived mesenchymal stem cells inhibit, but adipose tissue-derived mesenchymal stem cells promote, glioblastoma multiforme proliferation. Stem Cells Dev 22: 1370-1386, 2013.
95. Bussolati B, Dekel B, Azzarone B and Camussi G: Human renal cancer stem cells. Cancer Lett 338: 141-146, 2013.

96. Grange C, Tapparo M, Collino F, Vitillo L, Damasco C, Deregibus MC, Tetta C, Bussolati B and Camussi G: Microvesicles released from human renal cancer stem cells stimulate angiogenesis and formation of lung premetastatic niche. Cancer Res 71: 5346-5356, 2011.

97. Todaro M, Alea MP, Di Stefano AB, Cammareri P, Vermeulen L, Iovino F, Tripodo C, Russo A, Gulotta G, Medema JP and Stassi G: Colon cancer stem cells dictate tumor growth and resist cell death by production of interleukin-4. Cell Stem Cell 1: 389-402, 2007.

98. Francipane MG, Alea MP, Lombardo Y, Todaro M, Medema JP and Stassi G: Crucial role of interleukin-4 in the survival of colon cancer stem cells. Cancer Res 68: 4022-4025, 2008.

99. Conticello C, Pedini F, Zeuner A, Patti M, Zerilli M, Stassi G, Messina A, Peschle C and De Maria R: IL-4 protects tumor cells from anti-CD95 and chemotherapeutic agents via up-regulation of antiapoptotic proteins. J Immunol 172: 5467-5477, 2004

100. Todaro M, Zerilli M, Ricci-Vitiani L, Bini M, Perez Alea M, Maria Florena A, Miceli L, Condorelli G, Bonventre S, Di Gesu G, De Maria R and Stassi G: Autocrine production of interleukin-4 and interleukin-10 is required for survival and growth of thyroid cancer cells. Cancer Res 66: 1491-1499, 2006.

101. Emmink BL, Verheem A, Van Houdt WJ, Steller EJ, Govaert KM, Pham TV, Piersma SR, Borel Rinkes IH, Jimenez CR and Kranenburg O: The secretome of colon cancer stem cells contains drug-metabolizing enzymes. J Proteomics 2013: 84-96, 2013

102. Long H, Xie R, Xiang T, Zhao Z, Lin S, Liang Z, Chen Z and Zhu B: Autocrine CCL5 signaling promotes invasion and migration of $\mathrm{CD}_{133^{+}}$ovarian cancer stem-like cells via NF-kappaB-mediated MMP-9 upregulation. Stem Cells 30: 2309-2319, 2012.

103. Karnoub AE, Dash AB, Vo AP, Sullivan A, Brooks MW, Bell GW, Richardson AL, Polyak K, Tubo R and Weinberg RA: Mesenchymal stem cells within tumour stroma promote breast cancer metastasis. Nature 449: 557-563, 2007.

104. Dittmer J, Oerlecke I and Leyh B: Involvement of mesenchymal stem cells in breast cancer progression. In: Breast Cancer-Focusing Tumor Microenvironment, Stem Cells and Metastasis. Gunduz M and Gunduz E (eds). INTECH Open Access Publisher, Rijeka, pp247-272, 2011.

105. Liu S, Ginestier C, Ou SJ, Clouthier SG, Patel SH, Monville F, Korkaya H, Heath A, Dutcher J, Kleer CG, Jung Y, Dontu G, Taichman R and Wicha MS: Breast cancer stem cells are regulated by mesenchymal stem cells through cytokine networks. Cancer Res 71: 614-624, 2011.

106. Devarajan E, Song YH, Krishnappa S and Alt E: Epithelialmesenchymal transition in breast cancer lines is mediated through PDGF-D released by tissue-resident stem cells. Int J Cancer 131: 1023-1031, 2012.

107. Shipitsin M, Campbell LL, Argani P, Weremowicz S, BloushtainQimron N, Yao J, Nikolskaya T, Serebryiskaya T, Beroukhim R, Hu M, Halushka MK, Sukumar S, Parker LM, Anderson KS, Harris LN, Garber JE, Richardson AL, Schnitt SJ, Nikolsky Y, Gelman RS and Polyak K: Molecular definition of breast tumor heterogeneity. Cancer Cell 11: 259-273, 2007.

108. Hardt O, Wild S, Oerlecke I, Hofmann K, Luo S, Wiencek Y, Kantelhardt E, Vess C, Smith GP, Schroth GP, Bosio A and Dittmer J: Highly sensitive profiling of CD44(+)/CD24(-) breast cancer stem cells by combining global mRNA amplification and next generation sequencing: Evidence for a hyperactive PI3K pathway. Cancer Lett 325: 165-174, 2012.

109. Harbeck N, Schmitt M, Meisner C, Friedel C, Untch M Schmidt M, Sweep CG, Lisboa BW, Lux MP, Beck T, Hasmuller S, Kiechle M, Janicke F and Thomssen C: Ten-year analysis of the prospective multicentre Chemo-N0 trial validates American Society of Clinical Oncology (ASCO)recommended biomarkers UPA and PAI-1 for therapy decision making in node-negative breast cancer patients. Eur J Cancer 49: 1825-1835, 2013.

110. Dellas C and Loskutoff DJ: Historical analysis of PAI-1 from its discovery to its potential role in cell motility and disease. Thromb Haemost 93: 631-640, 2005.

111. Czekay RP, Wilkins-Port CE, Higgins SP, Freytag J, Overstreet JM, Klein RM, Higgins CE, Samarakoon R and Higgins PJ: PAI-1: An integrator of cell signaling and migration. Int J Cell Biol 2011: 562481, 2011. 
112. Hogan NM, Joyce MR, Murphy JM, Barry FP, O'Brien T, Kerin MJ and Dwyer RM: Impact of mesenchymal stem cell secreted PAI-1 on colon cancer cell migration and proliferation. Biochem Biophys Res Commun 435: 574-579, 2013.

113. Beck B, Driessens G, Goossens S, Youssef KK, Kuchnio A, Caauwe A, Sotiropoulou PA, Loges S, Lapouge G, Candi A, Mascre G, Drogat B, Dekoninck S, Haigh JJ, Carmeliet P and Blanpain C: A vascular niche and a VEGF-Nrp1 loop regulate the initiation and stemness of skin tumours. Nature 478 : 399-403, 2011.

114. Monzani E, Facchetti F, Galmozzi E, Corsini E, Benetti A, Cavazzin C, Gritti A, Piccinini A, Porro D, Santinami M, Invernici G, Parati E, Alessandri G and La Porta CA: Melanoma contains CD133 and ABCG2 positive cells with enhanced tumourigenic potential. Eur J Cancer 43: 935-946, 2007.

115. Maeda S, Shinchi H, Kurahara H, Mataki Y, Maemura K, Sato M, Natsugoe S, Aikou T and Takao S: CD133 expression is correlated with lymph node metastasis and vascular endothelial growth factor- $\mathrm{C}$ expression in pancreatic cancer. $\mathrm{Br} \mathrm{J}$ Cancer 98: 1389-1397, 2008.

116. Romagnani $\mathrm{P}$ and Anders $\mathrm{HJ}$ : What can tubular progenitor cultures teach us about kidney regeneration? Kidney Int 83: 351-353, 2013.
117. Calabrese C, Poppleton H, Kocak M, Hogg TL, Fuller C, Hamner B, Oh EY, Gaber MW, Finklestein D, Allen M, Frank A, Bayazitov IT, Zakharenko SS, Gajjar A, Davidoff A and Gilbertson RJ: A perivascular niche for brain tumor stem cells. Cancer Cell 11: 69-82, 2007.

118. Eyler CE and Rich JN: Survival of the fittest: cancer stem cells in therapeutic resistance and angiogenesis. J Clin Oncol 26: 2839-2845, 2008

119. Ghajar CM, Peinado H, Mori H, Matei IR, Evason KJ, Brazier H, Almeida D, Koller A, Hajjar KA, Stainier DY, Chen EI, Lyden D and Bissell MJ: The perivascular niche regulates breast tumour dormancy. Nat Cell Biol 15: 807-617, 2013.

120. Descot A and Oskarsson T: The molecular composition of the metastatic niche. Exp Cell Res 319: 1679-1686, 2013.

121. Gupta PB, Onder TT, Jiang G, Tao K, Kuperwasser C, Weinberg RA and Lander ES: Identification of selective inhibitors of cancer stem cells by high-throughput screening. Cell 138: 645-659, 2009.

122. Bottos A and Bardelli A: Oncogenes and angiogenesis: a way to personalize anti-angiogenic therapy? Cell Mol Life Sci 70: 4131-4140, 2013. 